\title{
PROBLEMS EXAMINATION IN QUALITY MANAGEMENT SYSTEM
}

\author{
Mariusz J. LIGARSKI \\ Silesian University of Technology, Gliwice, Poland
}

\begin{abstract}
In the work, there was a method of problems examination presented in the certified quality management system according to the ISO 9001 standard. The own method of problems examination was suggested on the basis of reports from audits of the third party. There are method assumptions as well as practical application presented for the examination of nonconformities and weaknesses on a sample of 892 organizations certified by a chosen certifying body. Different types of compilations of obtained results are showed. Different possibilities of their application for the examination of relations of identified problems were indicated, depending on the size and profile of examined organizations. Different types of statistical tests were used in the method together with their possibilities. Concrete examples of uses of the method and statistical tests were provided for examining the relations between the size as well as profile of the organization and the number as well as type of nonconformities and weaknesses. It was attempted to determine what possibilities the method provides and to give the examples of its practical use. Additionally, an attention was paid to potential difficulties when applying the method.
\end{abstract}

Keywords: issues research, method, ISO 9001

In the world, over $1,000,000$ organizations possess a certified quality management system in compliance with requirements of the ISO 9000 series of standards. In Poland, the certification of systems started in year 1990 and currently over 10,000 organizations have the system. According to the ISO Survey-2008, at the end of 2008, this number amounted to 10,965 organizations (The ISO Survey-2008, 2009). Despite a high popularization of quality management systems, there are various problems appearing. Literature analysis during the last few years indicates the identification of various problems concerning the quality management systems (Hernandez, 2010; Rusjan and Alic, 2010; Sapaio et al., 2009; Srivastan, 2010). In Poland, various researches on quality management systems in conformity with the ISO 9000 series of standards were conducted. Evaluation instruments for normalized management systems were analyzed (Jedynak, 2006, 2007), and supporting factors and barriers in the implementation of quality systems in small organizations were determined (Grudowski, 2006a, 2006b). Conditions connected with the implementation of management systems were examined (Urbaniak, 2006a, $2006 \mathrm{~b})$, and methods of risk management in quality systems were determined (Ścierski, 2012). Attempts to parameterize the evaluation criteria of system's maturity were made (Wolniak, 2011). The author of the work has been conducting the research on certified quality management systems for many years (Ligarski, 2002, 2004, 2005, 2006, 2007a, 2007b, 2007 c, 2008, 2010). One of the research directions is to examine the problems appearing in the system (Ligarski and Koczaj, 2004; Ligarski and Krysztofiuk, 2005; Ligarski, 2010, 2011, 2012).

The author has elaborated his own method of problems examination, which consists in the analysis of results of thirdparty audits conducted. The assumption and description of this research method was presented by Ligarski (2012). The elaborated method may be qualified for research methods described as research based on documents. In order to identify the problems in the system, the author suggested investigating third-party audit reports prepared by auditors of certification bodies. The only possibility of researching problems in the quality management system, based on reports of third-party audits, is the research of nonconformities and weaknesses which were ascribed to particular clauses of the ISO 9001 standard. Despite the fact that audit reports may be treated as,occasional papers', i.e. documents the contents of which is highly subjective, created by the author, they provide valuable information concerning the problems existing in the system. Reports from third-party audits are prepared by professional auditors from certifying bodies who in the most part have high qualifications and substantial experience regarding quality management systems. Obtaining such results provides a relatively independent, as it is performed from the position of an external unit, view of the problems existing in the system. In order to achieve the most impartial results possible, only data concerning nonconformities and weaknesses were chosen to be analysed. In the research, the analysis was conducted on the results of certifying audits, control visits, recertifying audits and preliminary audits. Nonconformity is understood as formal requirements, determined by the ISO 9001 standard, not being met and which are being reported as nonconformity. The weakness of the system means that requirements are met, acceptable, but the areas that were assessed as meeting them constitute a weakness of the system and allow room for improvement.

The purpose of the paper is to present the own method of problems examination in the quality management system and indicate the possibilities provided by the method.

\section{Material and methods}

When trying to identify the problems in the quality management system, it was decided to examine the 
nonconformities and weaknesses in the system found during the audits of the third party. The selection of research sample was deliberate. The research was planned on the sample of all the organizations possessing a certified quality management system according to the ISO 9001 standard in the two big, international certifying bodies belonging to the group of organizations having the highest share in the certification of quality management systems in Poland. In the work, there will be presented a part of the obtained results concerning the certifying body, without providing its name, and to maintain the order, it will be marked as the certifying body A. The research was conducted on the sample of 892 organizations possessing the certified quality management system according to the ISO 9001 standard and being the customers of the examined certifying body $A$. The organizations under the research were classified depending on the size and profile of activity. The size of examined organizations was determined on the basis of the number of employees, with indicating their four types: small, medium, large and very large. The organizations were also divided according to the profile of activity into production and service ones. In case when the certification object was conducting the production and service activity, the organizations were ascribed to a particular category on the basis of their main activity. The research concentrated on problems determination in the quality management system and linking them with the size and profile of organization. There were the following types of listings elaborated: identified nonconformities and weaknesses in relation to particular sections of the ISO 9001 standard, identified nonconformities and weaknesses in accordance with organization's size, average number of nonconformities and weaknesses per one organization in connection with its size, identified nonconformities and weaknesses related to organization's profile, and average number of nonconformities and weaknesses per one organization in connection with organization's profile. Appropriate statistical tests were conducted in order to check whether there is a relation between the organization's size and types of nonconformities and weaknesses identified as well as between the organization's profile and types of nonconformities and weaknesses identified. The $\chi^{2}$ independence test was used to determine the relation between the organization's size and types of identified nonconformities or weaknesses in particular sections of the ISO standard and to determine the relations between the organization's profile and types of identified nonconformities or weaknesses in particular sections of the ISO standard. The equality test of multiple means was used for examining the average number of nonconformities or weaknesses related to one organization. In order to conduct such tests, it was confirmed whether the assumptions concerning its applicability are met: whether the values of observation come from the population of normal distribution or similar to normal one - Hellwig's compatibility test, and whether variations for separate populations are equal - Hartley's test concerning variations equality in many populations. There was also adopted the equality test of two means for unknown equal standard deviations, equality test of two means for unknown different standard deviations - WelchAspin's test as well as two fractions equality test. The detailed information concerning the statistical tests used and the results of the analysis are presented by Ligarski (2011).

\section{Results and discussion}

Problems examination in the quality management system using the reports analysis method from audits of the third party provides great possibilities. The obtained information about nonconformities and weaknesses was discovered when conducting the audits by independent external auditors. It gives the picture of problems occurring in the organization, identified from the point of view of the external body supervising the system. On the basis of the information obtained, there may be different listings built, and using statistical tests the hypotheses stated could be confirmed. When analysing the obtained results for 892 organizations certified in the certifying body $A$, there may be interesting compilations of results elaborated.

An example of the first listing is the attribution of identified nonconformities and weaknesses to particular sections of the ISO 9001 standard (Table 1). It provides the possibility to determine sections of the standard in which there were the most problems found, that is to find such requirements of the standard that bring the most difficulties for the organization. Having the results from a few certifying bodies at disposal, there may be the problems comparison made.

In the exemplary listing (Table 1), the most nonconformities were identified in the following sections of the ISO 9001 standard: 5.6 Management review, 8.2 Monitoring and measurement, 8.5 Improvement, 4.2 Requirements for documentation, 6.2 Human resources and 7.6 Control of monitoring and measuring devices. The most weaknesses were identified in the following sections of the ISO 9001 standard: 8.2 Monitoring and measurement, 4.2 Requirements for documentation, 8.5 Improvement, 6.2 Human resources, 5.4 Planning and 7.4 Purchasing. Therefore, the sections repeated in each listing may be indicated. It proves the existence of a group of problems appearing in most of the organizations and consequently, they may be treated as the major problems. Managing information from several different certifying bodies, it becomes possible to identify the major problems occurring in all the organizations.

The second type of listings that can be elaborated are listings of identified nonconformities or numbers of weaknesses in relation to the sections of the ISO 9001 standard in small (1-50 employees), medium (51-250 employees), large (251-500 employees) or very large organizations (more than 501 employees). The exemplary compilation of the number of weaknesses in accordance with the sections of the standard in organizations of different sizes is presented in Table 2.

This type of listing may serve for confirmation of the hypothesis whether there is a relation between the organization's size and the types of weaknesses identified. In the analysed case (Table 2), using the chisquare independence test in the listing of the number of weaknesses in particular areas of the system, depending on the organization's size certified by the body $A$ on 
Table 1 Nonconformities and weaknesses identified in relation to the particular clauses of the ISO 9001 standard in organizations certified by the body A

\begin{tabular}{|c|c|c|c|c|}
\hline \multirow[t]{2}{*}{ Clauses of the ISO 9001 standard } & \multicolumn{4}{|c|}{ Body A } \\
\hline & $\begin{array}{c}\text { Number of } \\
\text { non-conformities }\end{array}$ & $\begin{array}{l}\text { Percentage } \\
\text { share }\end{array}$ & $\begin{array}{c}\text { Number of } \\
\text { weaknesses }\end{array}$ & $\begin{array}{c}\text { Percentage } \\
\text { share }\end{array}$ \\
\hline 4.1 General requirements & 5 & 4.07 & 370 & 4.64 \\
\hline 4.2 Documentation requirements & 14 & 11.38 & 770 & 9.65 \\
\hline 5.1 Management commitment & 1 & 0.81 & 75 & 0.94 \\
\hline 5.2 Customer focus & 0 & 0.00 & 58 & 0.73 \\
\hline 5.3 Quality policy & 2 & 1.63 & 101 & 1.26 \\
\hline 5.4 Planning & 4 & 3.25 & 507 & 6.35 \\
\hline 5.5 Responsibility, authority and communication & 1 & 0.81 & 250 & 3.13 \\
\hline 5.6 Management review & 20 & 16.26 & 347 & 4.35 \\
\hline 6.1 Provision of resources & 1 & 0.81 & 126 & 1.58 \\
\hline 6.2 Human resources & 8 & 6.50 & 507 & 6.35 \\
\hline 6.3 Infrastructure & 1 & 0.81 & 241 & 3.02 \\
\hline 6.4 Work environment & 2 & 1.63 & 180 & 2.25 \\
\hline 7.1 Product planning & 2 & 1.63 & 199 & 2.49 \\
\hline 7.2 Customer-related processes & 1 & 0.81 & 268 & 3.36 \\
\hline 7.3 Design and development & 5 & 4.07 & 280 & 3.51 \\
\hline 7.4 Purchasing & 4 & 3.25 & 402 & 5.04 \\
\hline 7.5 Production and service provision & 5 & 4.07 & 304 & 3.81 \\
\hline 7.6 Control of monitoring and measuring devices & 8 & 6.50 & 295 & 3.70 \\
\hline 8.1 General provisions & 0 & 0.00 & 124 & 1.55 \\
\hline 8.2 Monitoring and measurement & 19 & 15.44 & 1,269 & 15.90 \\
\hline 8.3 Control of nonconforming product & 3 & 2.44 & 223 & 2.79 \\
\hline 8.4 Data analysis & 2 & 1.63 & 349 & 4.37 \\
\hline 8.5 Continual improvement & 15 & 12.20 & 737 & 9.23 \\
\hline Total & 123 & 100.00 & 7,982 & 100.00 \\
\hline
\end{tabular}

a significance level $\alpha=0.001$, it was determined that there is no relation between the organization's size and the types of weaknesses identified in the particular sections of the standard. Thus, it proves that the types of weaknesses identified do not depend on the organization's size.

The third type of listings that can be elaborated are compilations of the average number of nonconformities or weaknesses per one organization, identified in the particular sections of the standard in small, average, large and very large organizations. Taking into account the exemplary listing of the number of weaknesses in relation to the sections of the standard in organizations of different size, presented in Table 2, the next step is to elaborate a compilation of the average number of weaknesses per one organization, identified in the particular sections of the standard in small, average, large and very large organizations. This type of compilation enables confirming the hypothesis stated with the use of many means equality. In the analysed case, at the significance level $a=0.001$, using the many means equality test, having checked its applicability, it was determined that the differences between the means are not statistically significant. Therefore, it may be stated that the average number of weaknesses identified in these organizations does not depend on their size. Additionally, depending on the obtained results, there may be other statistical tests conducted: equality test of two means for unknown equal standard deviations, equality test of two means for unknown different standard deviations - Welch-Aspin's test and equality test of two fractions. The tests conducted should provide an answer to a question whether there is a relation between the organization's size and the types of nonconformities and weaknesses identified. In the research conducted, for which the exemplary compilations are presented in Table 1 and Table 2, when making a summary of the statistical analyses conducted, it was determined that the number and type of nonconformities identified in the implemented quality management system are not related to the organization's size. The results of the tests confirm it: chi-square independence test, equality test of means and equality test of two fractions, conducted for all the results 
Table 2 The listing of the number of identified weaknesses in relation to the particular clauses of the ISO 9001 standard in small, medium-sized, large and very large organizations certified by the body A

\begin{tabular}{|c|c|c|c|c|}
\hline \multirow[t]{2}{*}{ Specification } & \multicolumn{4}{|c|}{ Number of weaknesses identified in organizations } \\
\hline & small & medium-sized & large & very large \\
\hline 4.1 General requirements & 206 & 133 & 14 & 17 \\
\hline 4.2 Documentation requirements & 440 & 266 & 37 & 27 \\
\hline 5.1 Management commitment & 44 & 26 & 4 & 1 \\
\hline 5.2 Customer focus & 30 & 22 & 5 & 1 \\
\hline 5.3 Quality policy & 53 & 37 & 4 & 7 \\
\hline 5.4 Planning & 297 & 172 & 25 & 13 \\
\hline 5.5 Responsibility, authority and communication & 137 & 93 & 13 & 7 \\
\hline 5.6 Management review & 210 & 112 & 18 & 7 \\
\hline 6.1 Provision of resources & 71 & 44 & 7 & 4 \\
\hline 6.2 Human resources & 269 & 195 & 31 & 12 \\
\hline 6.3 Infrastructure & 125 & 92 & 12 & 12 \\
\hline 6.4 Work environment & 97 & 65 & 10 & 8 \\
\hline 7.1 Product planning & 117 & 70 & 6 & 6 \\
\hline 7.2 Customer-related processes & 148 & 97 & 10 & 13 \\
\hline 7.3 Design and development & 140 & 112 & 14 & 14 \\
\hline 7.4 Purchasing & 222 & 145 & 20 & 15 \\
\hline 7.5 Production and service provision & 158 & 128 & 11 & 7 \\
\hline 7.6 Control of monitoring and measuring devices & 174 & 101 & 13 & 7 \\
\hline 8.1 General provisions & 66 & 47 & 8 & 3 \\
\hline 8.2 Monitoring and measurement & 725 & 446 & 59 & 39 \\
\hline 8.3 Control of nonconforming product & 102 & 97 & 14 & 10 \\
\hline 8.4 Data analysis & 214 & 115 & 14 & 6 \\
\hline 8.5 Continual improvement & 417 & 261 & 35 & 24 \\
\hline Total & 4,462 & 2,876 & 384 & 260 \\
\hline
\end{tabular}

obtained concerning nonconformities and weaknesses. On this basis, it may be concluded that there is no relation between the organization's size and the number and types of nonconformities and weaknesses.

There may be the examination of relations occurring between the identified problems as well as weaknesses and organization's profile conducted in a similar way to the considerations conducted above. It will result in the elaboration of listings of the number of identified nonconformities or number of weaknesses in relation to the ISO 9001 standard in production and service organizations. The next step will be elaborating the average number of nonconformities or weaknesses per one organization, identified in the particular sections of the standard in production and service organizations. Next, using the statistical tests such as the chi-square independence test, accordingly the equality test of multiple means, equality test of two means for unknown equal standard deviations, equality test of two means for unknown different standard deviations and equality test of two fractions, there will be checked whether there is a relation between the organization's profile and the number and types of nonconformities and weaknesses. On this basis, it will be possible to conclude whether there are relations existing between the organization's profile and the number and types of nonconformities and weaknesses.

\section{Conclusion}

The presented method concerning problems examination in the quality management system using the analysis of reports of the third party provides great possibilities. It allows determining the number and types of nonconformities and weaknesses in the system and ascribing them to the particular sections of the ISO 9001 standard. It enables identifying the major problems occurring in the examined groups of organizations. Grounding on the results obtained, it is possible to elaborate various listings and examine the relations of problems identified depending on the size and profile of examined organizations. Using appropriate statistical tests, the relations between the organization's size and profile and the number and types of nonconformities and weaknesses may be examined. 
Having the information about organizations certified by various certifying bodies at disposal, it is possible to make comparisons of problems identified in particular groups of organizations. The examples presented in the work confirm the practical application of the method and its huge possibilities. The only difficulty that can be found when applying it could be the unwillingness of certifying bodies to provide access to data concerning the results of conducted audits of the third party.

\section{References}

GRUDOWSKI, P. 2006a. Czynniki wspierające oraz bariery przy wdrażaniu systemów jakości w małych organizacjach, cz. 1. In Problemy Jakości, 2006. no. 4, pp. 40-44.

GRUDOWSKI, P. 2006b. Czynniki wspierające oraz bariery przy wdrażaniu systemów jakości w małych organizacjach, cz. 2. In Problemy Jakości, 2006. no. 5, pp. 34-39.

HERNANDEZ, H. 2010. Quality audit as a driver for compliance to ISO 9001:2008 standards. In The TQM Journal, 2010. no. 4, pp. 454-466. JEDYNAK, P. 2006. Ocena znormalizowanych systemów zarządzania w polskich organizacjach. In Problemy Jakości, 2006. no. 3, pp. 4-7. JEDNAK, P. 2007. Ocena znormalizowanych systemów zarządzania jakością. Instrumenty i uwarunkowania jakości (Monografia). Kraków : Wyd. Uniwersytetu Jagiellońskiego. 2007.

LIGARSKI, M.J. 2002. Normy ISO serii 9000 w polskich organizacjach historia i perspektywy. In Zeszyty Naukowe Politechniki Śląskiej Organizacja i Zarządzanie, Gliwice, 2002. no. 12, pp. 55-65.

LIGARSKI, M.J. 2004. Doświadczenia $z$ budowy systemów zarządzania jakością według norm ISO serii 9000 w samorządzie terytorialnym. In Przegląd Organizacji, 2004. no. 11, pp. 38-40.

LIGARSKI, M.J. 2005. Budowa systemów zarządzania jakością według norm ISO serii $9000 \mathrm{w}$ ochronie zdrowia. In Przegląd Organizacji, 2005. no. 7-8, pp. 66-69.

LIGARSKI, M.J. 2006. Czy certyfikowany system jakości przeszkadza w zarządzaniu organizacją. In Przegląd Organizacji, 2006. no. 9, pp. 35-38.

LIGARSKI, M.J. 2007a. System zarządzania jakością - szansa czy zagrożenie dla organizacji. In Przegląd Organizacji, 2007. no. 2, pp. 38-41.

LIGARSKI, M.J. 2007b. Pomiar skuteczności systemu zarządzania jakością w organizacji. In Ekonomika i Organizacja Przedsiębiorstwa, 2007. no. 5, pp. 79-84.

LIGARSKI, M.J. 2007c. Ocena systemu zarządzania jakością - wyniki badań. In Towaroznawcze Problemy Jakości, vol. 4, 2007. no. 13, pp. 25-35.
LIGARSKI, M.J. 2008. Czy system zarządzania jakością wg normy ISO 9001:2000 można z powodzeniem zastosować w bankowości. In Przegląd Organizacji, 2008. no 2, pp. 36-40.

LIGARSKI, M.J. 2010. Podejście systemowe do zarządzania jakością W organizacji. Gliwice : Wyd. Politechniki Śląskiej. 2010. ISBN 978-83-7335-723-5.

LIGARSKI, M.J. 2011. Problems in a certified quality management system - identification, mechanism of functioning, causes (habilitation dissertation). Gliwice : Silesian University of Technology.

LIGARSKI, M.J. 2012. Problem identification method in certified quality management systems. In Quality \& Quantity, vol. 46, 2012. pp. 315-321.

LIGARSKI, M.J. - KOCZAJ, K. 2004. Jakie wymagania normy ISO 9001:2000 sprawiają trudności polskim przedsiębiorstwom. In Problemy Jakości, 2004. no. 11, p. 24, pp. 29-33.

LIGARSKI, M.J. - KRYSZTOFIUK, J. 2005. Obszary sprawiające trudności w systemach zarządzania jakością według normy ISO 9001:2000. In Problemy Jakości, 2005. no. 10, pp. 32-39.

RUSJAN, B. - ALIC, M. 2010. Capitalising on ISO 9001 benefits for strategic results. In International Journal of Quality and Reliability Management, 2010. no. 7, pp. 756-778.

SAMPAIO, P. - SARAIVA, P. - RODRIGUES, A.G. 2009. ISO 9001 certification research: questions, answers and approaches. In International Journal of Quality and Reliability Management, 2009. no. 1, pp. 38-58.

SRIVASTAV, A.K. 2010. Impact of ISO 9000 implementation on the organization. In International Journal of Quality and Reliability Management, 2010. no. 4, pp. 438-450.

ŚCIERSKI, J. 2012. Risk management in normalized quality systems. In Zborník vedeckých prác: Aktuálne problémy podnikovej sféry. Ekonomicka Univerzita $v$ Bratislave. Bratislava : Vydavatel'stvo Ekonóm, 2012. s. 454-462.

The ISO Survey - 2008. 2009. ISO, Geneve.

URBANIAK, M. 2006a. Przesłanki związane z wdrażaniem systemów zarządzania, cz. 1. In Problemy Jakości, 2006. no. 6, pp. 27-32.

URBANIAK, M. 2006b. Korzyści wynikające $z$ wdrożenia systemów zarządzania, cz. 2. In Problemy Jakości, 2006. no. 7, pp. 21-25.

WOLNIAK, R. 2011. Parametryzacja kryteriów oceny poziomu dojrzałości systemu zarządzania jakością (Monografia). Gliwice : Wyd. Politechniki Śląskiej. 2011.

\section{Contact address:}

dr habt. inż. Mariusz J. Ligarski, Silesian University of Technology, Faculty of Organization and Management, Institute of Production Engineering, Division of Quality Management of Process and Product, ul. Roosevelta 26-28, 41-800 Zabrze, Poland, e-mail: Mariusz.Ligarski@polsl.pl 